Proceedings of the 33rd Annual Meeting of the Brazilian Embryo Technology Society (SBTE); Ilha de Comandatuba, BA, Brazil, August 15th to 19th, 2019.

\title{
Contribution of the immune system to follicle differentiation, ovulation and early corpus luteum formation
}

\author{
Noof Abdulrahman, Trudee Fair* \\ School of Agriculture \& Food Sciences, University College Dublin, Belfield, Dublin 4, Ireland.
}

\begin{abstract}
Much of what we know about the involvement of the immune system in periovulatory follicle differentiation, ovulation and subsequent formation of the corpus luteum in cattle is drawn from the findings of studies in several mammalian livestock species. By integrating published histological data from cattle, sheep and pigs and referring back to the more comprehensive knowledge bank that exists for mouse and humans we can sketch out the key cells of the immune system and the cytokines and growth factors that they produce that are involved in follicle differentiation and luteinization, ovulation and early follicle development. These contributions are reviewed and the key findings, discussed.
\end{abstract}

Keywords: bovine, ovulation, corpus luteum.

\section{Introduction}

Optimum fertility underlies all livestock production systems and by it's nature reflects the metabolic and immunological health status of the animal. Exposure to environmental insults such as heat stress, undernutrition and drought, metabolic and pathogenic disease have well-documented negative consequences for female fertility (Fair, 2010). In dairy cattle the period from 3 weeks pre-calving to 3 weeks post-calving, known as the transition period, has been the subject of much focus and there is substantial scientific evidence that it exerts a profound effect on the animal's metabolic, immune and endocrine systems. Transition dairy cows become immunosuppressed due to lower dry matter intake, increased exposure to bacteria, and increased non-esterified fatty acid, betahydroxybutarate, concentrations and therefore more susceptible to increased incidence of endometritis and metritis, generally associated with reduced productivity and poor fertility in the rebreeding period (Sheldon et al., 2009; Thatcher et al., 2010; Giuliodori et al., 2013). Oocyte quality is considered a major contributor to the low fertility of these animals (Fair, 2010; Leroy et al., 2015), but so too is corpus luteum (CL) function (Niswender et al., 1994) and the endometrial environment. If we consider the ontogeny of the CL and it's primary function when formed, it is obvious that these key contributory factors are intricately related. Moreover, numerous studies have outlined an integral role for immune cells in follicular development (Fukumatsu et al., 1992), steroidogenesis (Petrovská et al., 1996), ovulation (Brännström and Enskog, 2002) and CL formation and regression (Pate et al., 2010). Thus it is likely that as the immune and endocrine systems coordinate the normal development and functioning of these tissues (Hansen et al., 2010), their susceptibility to modulation by adverse metabolic and environmental environments will act as the primary conduit by which oocyte quality and CL function will be compromised. Taking this statement as our hypothesis, the aim of this manuscript is to review the molecular and cellular involvement of the cow's immune system in follicle differentiation, ovulation and corpus luteum formation.

\section{Follicle differentiation and luteinization}

Differentiation of the dominant follicle is associated with granulosa cell proliferation, increased intrafollicular concentration of estradiol (E2) and a switch from follicle stimulating hormone (FSH) to luteinizing hormone (LH)- responsiveness as they develop. Following the preovulatory gonadotropin surge, these estrogen-active follicles lose their capacity to produce E2, for detailed information see the excellent review by Ireland et al., (Ireland et al., 2000). The subsequent switch from E2 dominance to progesterone (P4) dominance in the follicular fluid of preovulatory follicles in the period between the LH surge and ovulation signals the onset of follicle luteinization (Dieleman et al., 1983). Pre-ovulatory follicle differentiation and luteinization appear to be characterized by an immune-cell specific temporal influx of leukocytes likely initiated in response to the high E2 concentration and various other chemoattractant cues produced by the developing follicle (Townson and Liptak, 2003). Histological analysis of dominant follicles from cattle, revealed that the first influx of cells is constituted by granular leukocytes, primarily mast cells, which infiltrate the theca layer of the follicle. Based on findings from sheep and pigs, it has been proposed that the mast cells in the theca layer become activated, likely in response to the LH surge and release the contents of their granules. Mast cell granules contain many factors, of which it is likely that tumour necrosis factor-alpha (TNF- $\alpha$ ), recruits additional granular leukocytes such as eosinophils and neutrophils (Murdoch and Steadman, 1991; Standaert, et al., 1991). Following the peak in oestradiol concentration in the differentiated dominant follicle, the final phase of leukocyte infiltration, an influx of phagocytic monocytes occurs more or less in parallel with ovulation 
(Murdoch and Steadman, 1991; Standaert, et al., 1991). At the molecular level, several reports have detailed the transcriptomic profile of ovarian follicle development in cattle: (Li et al., 2009; Gilbert et al., 2011; Walsh et al., 2012a; Christenson et al., 2013; Hatzirodos et al., 2014). Deep sequencing analysis of bovine follicular theca and granulosa tissue during preovulatory follicle development, have revealed dynamic expression of many genes within immune-related pathways according to the stage of follicle development. Pathways associated with cell proliferation, tissue vascularization and angiogenesis were overpopulated during follicle differentiation (Walsh et al., 2012a), these processes are understood to be carried out by macrophages in the theca layer of the differentiating follicle (Fraser, 2006; Turner et al., 2011). Following the surge in the pituitary gonadotrophin $\mathrm{LH}$, preovulatory follicle development is directed away from differentiation and towards luteinization, initiating the earliest stages of CL development (Richards et al., 2008). In particular, the LH surge sharply increases the local production of the 2 angiogenic factors, basic fibroblast growth factor (FGF) 2 (Berisha et al., 2006) and vascular endothelial growth factor (VEGF) A (Schams et al., 2001), as the integrity of the basement membrane between the theca and granulosa-cell layers breaks down (Dieleman et al., 1983), the movement of leukocytes from the theca layer into the granulosa tissue is permitted and angiogenesis, required for $\mathrm{CL}$ formation is initiated.

\section{Ovulation}

The biochemical events of mammalian ovulation have been likened to an acute inflammatory response, owing to the participation of leucocytes, classical inflammatory mediators as well as proteolytic enzymes (Richards et al., 2008). Based on data from studies in mice it is accepted that the initiation of the ovulatory process occurs primarily in granulosa cells (Richards et al., 2002; 2008). Indeed, the gene expression profile of bovine peri-ovulatory granulosacells is enriched with factors involved in acute inflammation and immunosurveillance (Walsh et al., $2012 b$ ). The expression of these factors by the granulosa cells may activate the ovarian innate immune system (Spanel-Borowski, 2011), as evidenced by the detection of acute phase proteins, defensins, interleukins and prostaglandins (PGs) in the pre-ovulatory follicular tissue and fluid (Takeda, 2004; Angelucci et al., 2006; Poulsen et al., 2019). Based on findings in rats, it is proposed that PGs and leukotrienes stimulate the synthesis and activity of collagenases which act to promote the degradation of the follicle matrix (Murdoch and Gottsch, 2003). While some of these factors may be expressed or secreted by the immune cells immigrating from the theca layer, it is likely that the damaged granulosa cells actively or passively release tissue damage signals initiating a pre-ovulatory inflammatory cascade. Typically an inflammatory cascade involves the activation of endothelial cells and local leucocytes, leading to the recruitment and accumulation of additional leucocytes, vascular endothelial cells and plasma proteins. Within the peri-ovulatory follicle, the cytokines TNF- $\alpha$ and interleukin-1 (IL-1) promote inflammatory associated processes, such as an increase in intrafollicular pressure, the activation of proteolytic pathways, collagenases and initiation of angiogenesis and tissue destruction and repair. These processes lead to the reorganization of the follicular stroma, extensive remodelling of the extracellular matrix and loss of the follicle's surface epithelium, which result in a weakening in the follicle so that finally the follicle ruptures, expelling the cumulus enclosed mature oocyte and the follicle is transformed into a wound-like structure, the corpus hemorrhagica.

\section{Oocyte maturation}

Ovulation is initiated by the LH surge which acts directly on the theca and mural granulosa cells of the follicle. However, the preovulatory oocyte does not express the LH receptor, and expression in the surrounding cumulus cells is very low (Lawrence et al., 1980), therefore the propagation of the LH stimulus throughout the follicle to the oocyte is mediated by secondary molecules, which initiate oocyte maturation. Oocyte maturation comprises expansion and proliferation of the cumulus cell layers, oocyte nuclear maturation, i.e. dissolution of the nuclear membrane and the resumption of meiosis, reorganization of the oocyte cytoplasmic organelles and a dramatic increase in protein synthesis and activation of molecular pathways (Fair, 2003; 2010). The propagators of the LH signal in the preovulatory follicle have been identified as three members of the epidermal growth factor (EGF)-family, the EGF-like peptides amphiregullin (AREG), epiregulin (EREG) and beta-cellulin (BTC) (Park et al., 2004). The ovulatory LH surge induces an acute upregulation of the EGF signalling network in mural granulosa cells, which is transmitted to the cumulus cells. This leads to initiation of mural granulosa cell luteinisation, production of an extensive extracellular matrix by cumulus cells and the closure of gap junctional communication between the oocyte and the cumulus cells. At the same time, the meiotic inhibitory signalling network mediated by C-type natriuretic peptide (CNP) and cyclic guanosine monophosphate (cGMP) in mural granulosa and cumulus cells is downregulated, leading to oocyte meiotic maturation (see Richani and Gilchrist for review) (Richani and Gilchrist, 2018). It is noteworthy that the amplification and propagation of the EGF signal from the mural to cumulus cells is dependent on the LH-induced production of $\mathrm{PGE}_{2}$ in mural granulosa cells (Shimada et al., 2006). Furthermore, oocytes are not directly responsive to EGF-like peptides (Conti et al., 2006; Park et al., 2004), therefore, the LH/EGF-peptide ovulatory signal is transmitted to the oocyte via the EGF receptor on cumulus cells. It has been hypothesized the acquisition of EGF signalling capabilities by the mural granulosa and cumulus cells is important and likely to represent a milestone in oocyte development and acquisition of competence (Ritter et al., 2015). 


\section{Corpus Luteum Formation}

The corpus hemorrhagica arises from the collapsed post-ovulatory follicle. Morphologically it resembles a fresh wound, but it is actually heterogeneous in nature, composed of multiple, distinctive cell types including steroidogenic cells, large and small luteal cells, which originate from the granulosa and thecal cells of the follicle ruptured at ovulation, as well as resident and migrating vascular endothelial cells, fibroblasts and immune cells (Lobel and Levy, 1968; Lei, et al., 1991; Spanel-Borowski et al., 1997; Penny et al., 1999; Bauer, et al., 2001; Davis and Pate, 2007).

\section{Immune system in the developing $C L$}

Immediately after ovulation, in parallel with the onset of the differentiation of the follicular steroidogenic cells into luteal cells, resolution of the inflammation and consequential tissue damage must occur. This is initiated by immune cells recruited during ovulation (Murdoch and McCormick, 1993; Oakley et al., 2010; Watanabe et al., 1997; Gaytán et al., 1998). Chemoattractant cytokines (e.g., chemokines IL-8 and C-C motif ligand 5 and 2), produced by the endothelial, fibroblast and immune -cells, establish concentration gradients within the CL, which recruit and direct immune cell migration, primarily granulocytes, neutrophils and eosinophils that have originated in the spleen (Penny et al., 1999; Lobel and Levy, 1968; Spanel-Borowski et al., 1997; Jiemtaweeboon et al., 2011; Shirasuna et al., 2012). Immune cell migration is also enabled by the expression of ligands on immune cells, which interact with adhesion molecules on endothelial cells. Eosinophils are recognized as actors in the innate immune response to parasitic infections, asthma, and allergic conditions. Therefore, it is interesting to note that there is a rapid influx of eosinophils into the CL shortly after ovulation in cattle (Reibiger and Spanel-Borowski, 2000). The expression of P-selectin on endothelial cells appears to recruit eosinophils into the developing CL (Aust et al., 2000; Rohm et al., 2002). The arrival of these first responders, appears to be an important, but not essential, stimulus for angiogenesis during the early stages of CL development, as dexamethasone- induced eosinopenia resulted in lowered plasma $\mathrm{P} 4$ concentrations and reduced CL VEGFA protein production in cattle (Kliem et al., 2013). Moreover, the role of eosinophils appears to be restricted to the repair of the site of follicle rupture and early CL development as they are barely detectable later in the oestrous cycle when the CL is well established, or at the end of the cycle during CL regression (Reibiger and Spanel-Borowski, 2000; Rohm et al., 2002; Jiemtaweeboon et al., 2011).

Similar to eosinophils, neutrophils are important in the primary, nonspecific stages of acute inflammatory reactions and were also observed in large numbers, along with a high level of IL-8 (a potent neutrophilic chemoattractant), during the early luteal phase (d 1-4 of the estrous cycle) in the CL of cows
(Jiemtaweeboon et al., 2011). They too appear to be integral to the resestablishment of the local microvasculature and the promotion of the acute inflammatory cascade, as both PMN and IL-8 were reported to induce angiogenesis in vivo (Koch et al., 1992; Komatsu et al., 2003) and in vitro (Schruefer et al., 2005). These findings were verified in bovine CL tissue in a series of in vitro experiments, where Jiemtaweeboon et al. (2011) demonstrated that supernatant from cultures of early CL tissue could induce PMN migration in vitro and increase PMN IL-8 production. Moreover, IL-8 stimulated endothelial cells of the CL to form capillary-like structures, indicating that IL-8 acts as a major PMN chemoattractant and a strong stimulator of angiogenesis in the early CL (Jiemtaweeboon et al., 2011). The concept of functional polarization of neutrophils (classic proinflammatory versus novel anti-inflammatory) has been proposed to explain their action in angiogenesis (Fridlender et al., 2009). Concomitant with vascular angiogenesis, macrophages and endothelial cells infiltrate the developing CL. The number of macrophages and monocytes in the CL increases during the early stages of development in cows, but they are substantially fewer in number compared to during CL regression (Penny et al., 1999; Lawler et al., 1999; Townson et al., 2002). In response to local cytokines and other signals, macrophages differentiate to acquire a functional phenotype that is specific to the requirements of the tissue. Within the developing CL, these cells produce and secrete various cytokines, such as TNF- $\alpha$, interferon gamma, interleukins, PGs and angiogenic growth factors (Sakumoto et al., 2000; Townson and Liptak, 2003). The cytokine, TNF, is a potent stimulator of luteal PGs including PGF2 $\alpha$, PGE2 and PGI2 (Benyo and Pate, 1992; Sakumoto et al., 2000). Thus, TNF- $\alpha$ and TNF-induced PGE2 have been proposed as key regulators of CL vascularization (Okuda and Sakumoto, 2003; Korzekwa et al., 2008). A defined role for macrophages in promoting the vascularization of the developing CL is further substantiated by the findings of conditional macrophage ablation studies in mice, where it was shown that the ablation of macrophages in the early CL disrupted the ovarian vasculature and CL integrity (Turner et al., 2011).

There is very little evidence to suggest an essential involvement of $\mathrm{T}$ lymphocytes in the repair of the ovulatory site or the formation of the new CL. In fact, reports from several species, including bovine (Penny et al., 1999), buffalo (Ramadan et al., 2001), human (Best et al., 1996), pigs (Standaert et al., 1991) and sheep (Cavender and Murdoch, 1988), are equivacol in their descriptions of low numbers of $\mathrm{CD}^{+}$and $\mathrm{CD}^{+} \mathrm{T}$ lymphocytes in early to late luteal phase CL tissue and infiltration of larger populations during CL regression.

While, the immediate response to follicle differentiation, E2 production, the LH surge and subsequent ovulation is characterized by large numbers of PMN and macrophages, a substantial influx of endothelial cells also occurs. Moreover, these endothelial cells form the greatest cohort of 
proliferating cells in the early CL (Townson and Liptak, 2003; Reynolds and Redmer, 1999). Microvascular growth and development occur at an extremely rapid pace in female reproductive tissues and these tissues are highly vascular when mature. For example, most ( $~ 50$ $85 \%$ ) of luteal cell proliferation occurs in the microvascular compartment (Reynolds et al., 1992; Reynolds et al, 1998). As a result, in the mature CL, microvascular pericytes and endothelial cells comprise $50-70 \%$ of the total cell population (Farin et al., 1986; Lei et al., 1991)

\section{Angiogenesis in the CL}

In the ovary, the re-establishment of the luteal tissue microvasculature from pre-existing capillaries is a complex process that is necessary for the delivery of adequate levels of hormones and lipoprotein bound cholesterol into and out of the CL and ovary (Cherry et al., 2008) and is regulated by a number of growth factors. In cattle, peak expression of VEGF, its receptor VEGFR-2, FGF2, insulin-like growth factor (IGF), angiopoietin (ANPT) and hypoxia-inducible factor (HIF) family members has been reported from Day 0 - 4 of the oestrous cycle (Berisha et al., 2016; 2017; Castilho et al., 2019). The upregulation of these particular factors implies their particular importance for angiogenesis and maintenance of capillary structures during final follicle maturation and early CL development (Berisha et al., 2016). Luteal expression of VEGF occurs primarily in steroidogenic cells (granulose-lutein cells) and is regulated primarily by oxygen (Tropea et al., 2006). Hypoxia strongly induces angiogenesis, most likely through the HIF1-VEGF signalling pathway. Nitric oxide (NO) is produced by endothelial cells of luteal arterioles and capillaries; it is a potent vasodilator and stimulates endothelial cell proliferation, VEGF production and angiogenesis (Reynolds et al., 2000; Reynolds and Redmer, 1999). The purpose of luteal arteriole and capillary vasodilation is to facilitate increased blood flow and consequently delivery of peripheral immune cells to this site of tissue repair, regeneration and proliferation in the ovary. It is suggested that both FGF2 and VEGF play complementary roles in luteal angiogenesis (Robinson et al., 2009) as, FGF2 has also been shown to promote endothelial cell proliferation and appears to be critical to the initiation of the formation of the endothelial network in the bovine CL (Woad et al., 2009; Robinson et al., 2009). Furthermore, the suppression of VEGFA or FGF2 expression during the early luteal phase in cattle reportedly inhibited endothelial cell proliferation and reduced plasma P4 concentration (Kuhnert et al., 2008; Yamashita et al., 2008). A body of evidence also exists for a role for prostaglandins, including the luteolytic prostaglandin (PG) F2 $\alpha$ in promoting CL vascularization and supporting CL growth. Indeed PGF2 $\alpha$ has been shown to positively affect VEGF, FGF2, and P4 secretion in the bovine CL (Zalman et al., 2012; Miyamoto et al., 2010).

\section{Maintenance of the corpus luteum}

The LH surge is the main trigger of ovulation and luteinization. Progesterone regulates the length of the estrus cycle by influencing the timing of the luteolytic PGF2 $\alpha$ signal from the endometrium see review (Mishra and Palai, 2014). Furthermore, there is evidence to suggest that P4 may affect the secretory function of the bovine CL in a stage-dependent fashion, in an autocrine and paracrine manner that may be dependent on cell-to-cell contact and cellular makeup (Skarzynski and Okuda, 1999). For example, P4 affects the function of the early and mid CL in cattle (Skarzynski and Okuda, 1999; Duras et al., 2005), stimulating P4, oxytocin and prostaglandin secretion in the early CL, but later this is reversed as P4 inhibits PGF2a secretion in the mature CL. Recent studies have demonstrated that intra-luteal P4 is one of the most important factors supporting maintenance of the CL, acting to suppress apoptosis in bovine luteal cells through the inhibition of Fas and caspase- 3 mRNA expression and inhibition of caspase-3 activation (Rueda et al., 2000; Okuda et al., 2004). Progesterone may also act to keep ovarian immune cells in check, by supressing $\mathrm{T}$ lymphocyte proliferation (Cannon et al., 2003).

\section{Corpus Luteum Regression}

In the absence of an embryo(s) in the uterus, the process of CL regression begins on day 16 of the oestrous cycle in cattle (McCracken et al. 1999). Apoptosis of luteal cells and CL vascular regression are regulated by many different factors, however, in most species, uterine prostaglandin alpha (PGF2 $\alpha$ ) acts as the principal trigger for luteolysis. Although, it should be pointed out that there has been some debate about its direct action within the CL (Skarzynski and Okuda, 1999; Pate, 2003; Arosh et al., 2016). Nevertheless, PGF2 $\alpha$ has been proven to acutely decrease $\mathrm{P} 4$ secretion by inhibiting 3ß-Hydroxysteroid dehydrogenase (3ßHSD) and steroid acute regulatory protein (StAR) mRNA expression and other rate-limiting steroidogenic enzymes in vivo (Tsai and Wiltbank, 1998; Atli et al., 2012), The process of luteolysis are understood to proceed with PGF $2 \alpha$ induced angiolysis and vasoconstriction which limits the oxygen and nutrient supply to the tissue during luteolysis. Corpus luteum expression of members of the endothelin-1 (EDN1) system (EDN1, EDN converting enzymes, and EDNA and EDNB receptors) is upregulated by PGF2 $\alpha$ (Mamluk et al., 1999; Klipper et al., 2010) during luteal regression (Klipper et al. 2004; Choudhary et al., 2005; Rosiansky-Sultan et al., 2006). Meanwhile mediators of PGF2 a luteolysis, i.e., vasoactive peptides, i.e. angiotensin II and atrial natriuretic peptide, trigger the luteolytic cascade, decrease blood flow and consequently inhibit P4 secretion (Shirasuna et al., 2004). Endothelin 1 is believed to participate in luteal regression, by promoting leucocyte migration and stimulating macrophages to 
release cytokines, e.g. TNF- $\alpha$ and interferon-gamma (IFN- $\gamma$ ) (Girsh, et al., 1996); for review see also Smith and Meidan, 2014. Reportedly, TNF, TNF death receptors (TNF-RI), Fas and IFN $\gamma$ mRNA expression is significantly increased during luteolysis in bovine CL (Korzekwa et al., 2008). Because of the ability of these cytokines to induce apoptosis in CL endothelial cells, they have been proposed as key regulators of bovine luteolysis (Okuda et al., 1999; Hojo et al., 2010). Additionally, cytokine membrane receptors, second messengers, including calcium ions and regulatory proteins are involved in apoptosis of steroidogenic and endothelial CL cells (Petroff, and Pate, 2001).

\section{Immune cells in CL regression}

Luteal regression has been likened to an acute inflammatory process because of the short duration of luteolysis, the characteristic immune cell infiltration (neutrophils, macrophages, and $\mathrm{T}$ lymphocytes) and the dramatic change in vascular diameter and blood flow (Shirasuna et al., 2012). Many reports from several species describe an increase in lymphocytes or macrophages in the CL during luteolysis. Endothelial cell secretion of Monocyte chemoattractant protein 1 (also known as chemokine ligand 2 or CCL2), in direct response to TNF and IFN- $\gamma$ stimulation, has been implicated in the recruitment of immune cells into the CL during luteal regression (Townson et al., 2002). In particular, macrophages and $\mathrm{T}$ lymphocytes, are proposed to play a central role in structural and functional CL regression (Best et al., 1996; Penny et al., 1999; Bauer et al., 2001; Townson, et al., 2002; Pate et al., 2010). The phenotypes of T lymphocytes resident in the bovine CL were previously quantified before and after the induction of luteal regression. Prior to regression, and in contrast to their ratio in peripheral blood, the proportion of $\mathrm{CD}^{+}$-resident $\mathrm{T}$ cells was greater than $\mathrm{CD} 4^{+}$-resident $\mathrm{T}$ cells, however there was no difference in the proportion of $\gamma \delta+$ lymphocytes in the CL compared to peripheral blood, nor was the proportion altered during luteal regression (Poole and Pate, 2012). The proportion of $\mathrm{CD}^{+}$ Foxp $^{+}$cells (i.e., $\mathrm{T}$ regulatory cells) was greater in a functional CL, compared to a CL induced to regress. This lead the Authors, to propose that Foxp $3^{+}$cells may control the actions of activated resident $T$ lymphocytes to prevent premature luteal regression, but once luteal regression is initiated, a decline in the proportion the Foxp $3^{+}$cells weakens the inhibitory action on $\mathrm{T}$ lymphocytes, permitting their release of cytokines that may induce luteal cell death. In addition, the arrival of large numbers of monocytes, macrophages, and other cell types that create an inflammatory environment may augment the activity of the resident $\mathrm{T}$ lymphocytes.

It is truly remarkable that the activity of immune cells during luteolysis is confined to the CL and does not spread to the whole ovary, such tight control of inflammation ensures that CL tissue degradation remains localized with no effects on the surrounding tissue.

\section{Conclusion}

It is well recognized that cattle require an appropriately functioning immune system for a swift and healthy recovery from parturition. The extent to which the maternal immune system is involved in bovine fertility is somewhat overlooked, yet it's significant role in creating an appropriate microenvironment for final oocyte maturation, gamete transport and early embryo development reminds us that the immune system is intricately integrated in to the first stages of establishing pregnancy. Therefore, when seeking to optimize cow fertility, we should think first of the animal's immune system and try to maintain its integrity, particularly in husbandry situations that expose the animal to significant metabolic and physiological stress.

\section{Author contributions}

NAKA: Funding acquisition, Writing - original draft (Noof Abdulrahman $\mathrm{K}$ Al Rabiah); TF: Conceptualization, Supervision, Writing - original draft, Writing - review \& editing.

\section{Conflict of interest}

Authors declare no conflicts of interest.

\section{Acknowledgments and Funding disclosure statement}

NA is funded by the Saudi Arabian Culture Bureau.

\section{References}

Angelucci, S, Ciavardelli D, Di Giuseppe F, Eleuterio E, Sulpizio M, Tiboni GM, Giampietro F, Palumbo P, Di Ilio C. 2006. Proteome analysis of human follicular fluid. Biochim Biophys Acta, 1764(11):1775-1785.

Arosh, JA, Sakhila KB, McCracken JA. 2016. Novel concepts on the role of prostaglandins on luteal maintenance and maternal recognition and establishment of pregnancy in ruminants. J Dairy Sci, 99(7):5926-5940.

Atli MO, Bender RO, Mehta V, Bastos MR, Luo W, Vezina CM Wiltbank MC. 2012. Patterns of gene expression in the bovine corpus luteum following repeated intrauterine infusions of low doses of prostaglandin F2alpha1. Biol Reprod, 86(4):1-13.

Aust G, Heider SU, Hmeidan FA, Blumenauer V, Spanel-Borowski K. 2000. Eosinophils in the human corpus luteum: the role of RANTES and eotaxin in eosinophil attraction into periovulatory structures. Mol Hum Reprod, 6(12):1085-1091.

Bauer M, Reibiger I, Spanel-Borowski K. 2001. Leucocyte proliferation in the bovine corpus luteum. Reproduction, 121(2):297-305.

Benyo DF, Pate JL. 1992. Tumor necrosis factor- $\alpha$ alters bovine luteal cell synthetic capacity and viability. Endocrinology, 130:854-860.

Berisha B, Steffl M, Amselgruber W, Schams D. 
2006. Changes in Fibroblast growth factor 2 and its receptors in bovine follicles before and after GnRH application and after ovulation. Reproduction 131(2):319-329.

Berisha B, Schams D, Rodler D, Pfaffl MW. 2016. Angiogenesis in The Ovary - The most important regulatory event for follicle and corpus luteum development and function in cow - An Overview. Anat Histol Embryol, 45(2):124-130.

Berisha B, Schams D, Rodler D, Sinowatz F, Pfaffl MW. 2017. Expression pattern of HIF1alpha and vasohibins during follicle maturation and corpus luteum function in the bovine ovary. Reprod Domest Anim, 52(1):130-139.

Best CL, Pudney J, Welch WR, BurgerN Hill JA. 1996. Localization and characterization of white blood cell populations within the human ovary throughout the menstrual cycle and menopause. Hum Reprod, 11(4):790-797.

Brännström M, Enskog A. 2002. Leukocyte networks and ovulation. J Reprod Immunol, 57(1-2):47-60.

Cannon, MJ, Petroff MG, Pate JL. 2003. Effects of prostaglandin F2alpha and progesterone on the ability of bovine luteal cells to stimulate $\mathrm{T}$ lymphocyte proliferation. Biol Reprod, 69(2):695-700.

Castilho ACS, Dalanezi FM, Franchi FF, Price CA, Ferreira JCP, Trevisol E, Buratini J. 2019. expression of fibroblast growth factor 22 (FGF22) and Its receptor, FGFR1B, during development and regression of bovine corpus luteum. Theriogenology, 125:1-5.

Cavender JL, Murdoch WJ. 1988. Morphological studies of the microcirculatory system of periovulatory ovine follicles. Biol Reprod, 39(4):989-997.

Cherry JA, Hou X, Rueda BR, Davis JS, Townson DH. 2008. Microvascular endothelial cells of the bovine corpus luteum: a comparative examination of the estrous cycle and pregnancy. J Reprod Dev, 54(3):183-191.

Choudhary E, Sen A, Inskeep KE, Flores JA. 2005. Developmental sensitivity of the bovine corpus luteum to prostaglandin F2alpha (PGF2alpha) and endothelin-1 (ET-1): Is ET-1 a mediator of the luteolytic actions of PGF2alpha or a tonic inhibitor of progesterone secretion?. Biol Reprod, 72(3):633-642.

Christenson LK., Gunewardena S, Hong $X$, Spitschak M, Baufeld A, Vanselow J. 2013. research resource: preovulatory LH surge effects on follicular theca and granulosa transcriptomes. Mol Endocrinol, 27(7):1153-1171.

Conti M, Hsieh M, Park JY, Su YQ. 2006. Role of the epidermal growth factor network in ovarian follicles. Mol Endocrinol, 20(4):715-723.

Davis TL, Pate JL. 2007. bovine luteal cells stimulate proliferation of major histocompatibility nonrestricted gamma delta T cells. Biol Reprod, 77(6):914-922.

Dieleman SJ, Kruip TA, Fontijne P, de Jong WH, van der Weyden GC. 1983. Changes in oestradiol, progesterone and testosterone concentrations in follicular fluid and in the micromorphology of preovulatory bovine follicles relative to the peak of luteinizing hormone. $J$ Endocrinol, 97(1):31-42.
Duras M, Brzósko E, Kotwica J. 2005. Influence of progesterone, pregnenolone and 17betahydroxyprogesterone on the function of bovine luteal cells treated with luteinizing hormone, noradrenaline and prostaglandin E2. Pol J Vet Sci, 8(2):113-119.

Fair T. 2003. follicular oocyte growth and acquisition of developmental competence. Anim Reprod Sci, 78(34):203-216.

Fair T. 2010. Mammalian oocyte development: checkpoints for competence. Reprod Fertil Dev, 22(1):13-20.

Farin, CE, Moeller CL, Sawyer HR, Gamboni F, Niswender GD. 1986. Morphometric analysis of cell types in the ovine corpus luteum throughout the estrous cycle. Biol Reprod, 35(5):1299-1308.

Fraser HM. 2006. Regulation of the ovarian follicular vasculature. Reprod Biol Endocrinol, 18(4):1477-7827.

Fridlender ZG, Sun J, Kim S, Kapoor V, Cheng G, Ling L, Worthen GS, Albelda SM. 2009. polarization of tumor-associated neutrophil phenotype by TGF-Beta: “N1" versus “N2” TAN. Cancer Cell, 16(3):183-194.

Fukumatsu Y, Katabuchi H, Naito M, Takeya M, Takahashi K, Okamura K. 1992. Effect of macrophages on proliferation of granulosa cells in the ovary in rats. $J$ Reprod Fertil, 96(1):241-249.

Gaytán F, Morales C. García-Pardo L, Reymundo C, Bellido C, Sánchez-Criado JE. 1998. Macrophages, cell proliferation, and cell death in the human menstrual corpus luteum. Biol Reprod, 59(2):417-425.

Gilbert I, Claude R, Dieleman S, Blondin P, Sirard MA. 2011. Transcriptional effect of the LH surge in bovine granulosa cells during the peri-ovulation period. Reproduction, 141(2):193-205.

Girsh E, Milvae RA, Wang W, Meidan R. 1996. effect of endothelin-1 on bovine luteal cell function: role in prostaglandin F2alpha-induced antisteroidogenic action. Endocrinology, 137(4):1306-1312.

Giuliodori MJ, R. Magnasco P, Becu-Villalobos D, Lacau-Mengido IM, Risco CA, de la Sota RL. 2013. Clinical Endometritis in an argentinean herd of dairy cows: risk factors and reproductive efficiency. $J$ Dairy Sci, 96(1):210-218.

Hansen TR, Henkes LK, Ashley RL, Bott RC, Antoniazzi AQ, Han H. 2010. Endocrine actions of interferon-tau in ruminants. Soc Reprod Fertil Suppl, 67:325-340.

Hatzirodos N, Irving-Rodgers HF, Hummitzsch K, Harland ML, Morris SE, Rodgers RJ. 2014. Transcriptome profiling of granulosa cells of bovine ovarian follicles during growth from small to large antral sizes. BMC Genomics, 15(24):1471-2164.

Hojo T, Akihiro O, Lee SH, Acosta TJ, Okuda K. 2010. effects of tumor necrosis factor $\alpha$ and interferon $\gamma$ on the viability and MRNA expression of TNF receptor type I in endothelial cells from the bovine corpus luteum. J Reprod Dev, 56(5):515-519.

Ireland JJ, Mihm M, Austin E, Diskin MG, Roche JF. 2000. Historical perspective of turnover of dominant follicles during the bovine estrous cycle: key concepts, studies, advancements, and terms. J Dairy Sci, 83(7):1648-1658. 
Jiemtaweeboon S, Shirasuna K, Nitta A, Kobayashi A, Schuberth HJ, Shimizu T, Miyamoto A. 2011. Evidence That polymorphonuclear neutrophils infiltrate into the developing corpus luteum and promote angiogenesis with interleukin-8 in the cow. Reprod Biol Endocrinol, 79(9):1477-7827.

Kliem H, Rodler D, Ulbrich SE, Sinowatz F, Berisha B, Meyer HHD, Schams D. 2013. Dexamethasoneinduced eosinopenia is associated with lower progesterone production in cattle. Reprod Domest Anim, 48(1):137-148.

Klipper E, Gilboa T, Levy N, Kisliouk T, SpanelBorowski K, Meidan R. 2004. Characterization of endothelin-1 and nitric oxide generating systems in corpus luteum-derived endothelial cells. Reproduction, 128(4):463-73.

Klipper E, Levit A, Mastich Y, Berisha B, Schams D, Meidan R. 2010. Induction of endothelin-2 expression by luteinizing hormone and hypoxia: possible role in bovine corpus luteum formation. Endocrinology, 151(4):1914-1922.

Koch AE, Polverini PJ, Kunkel SL, Harlow LA, DiPietro LA, Elner VM, Elner SG, Strieter RM. 1992. Interleukin-8 as a macrophage-derived mediator of angiogenesis. Science, 258(5089):1798-1801.

Komatsu $K$, Manabe $\mathbf{N}$, Kiso $M$, Shimabe $M$, Miyamoto H. 2003. Changes in localization of immune cells and cytokines in corpora lutea during luteolysis in murine ovaries. J Exp Zool A Comp Exp Biol, Part A, 296(2):152-159.

Korzekwa A, Murakami S, Wocławek-Potocka I, Bah MM, Okuda K, Skarzynski DJ. 2008. The influence of tumor necrosis factor $\alpha$ (TNF) on the secretory function of bovine corpus luteum: TNF and its receptors expression during the estrous cycle. Reprod Biol, 8(3):245-262.

Kuhnert F, Tam BYY, Sennino B, Gray JT, Yuan J, Jocson A, Nayak NR, Mulligan RC, McDonald D, Kuo CJ. 2008. Soluble receptor-mediated selective inhibition of vegfr and pdgfrbeta signaling during physiologic and tumor angiogenesis. Proc Natl Acad Sci U S A, 105(29):10185-10190.

Lawler DF, Hopkins J, Watson ED. 1999. Immune cell populations in the equine corpus luteum throughout the oestrous cycle and early pregnancy: an immunohistochemical and flow cytometric study. $J$ Reprod Fertil, 117(2):281-290.

Lawrence TS., Dekel N, Beers WH. 1980. Binding of human chorionic gonadotropin by rat cumuli oophori and granulosa cells: a comparative study. Endocrinology, 106(4):1114-1118.

Lei ZM, Chegini N, Rao CV. 1991. Quantitative cell composition of human and bovine corpora lutea from various reproductive states. Biol Reprod, 44(6):11481156.

Leroy JLMR, Valckx SDM, Jordaens L, De Bie J, Desmet KLJ, Van Hoeck V, Britt JH, Marei WF, Bols PEJ. 2015. Nutrition and maternal metabolic health in relation to oocyte and embryo quality: critical views on what we learned from the dairy cow model. Reprod Fertil Dev, 27(4):693-703.

Li Q, Jimenez-Krassel F, Ireland JJ, and Smith GW.
2009. Gene expression profiling of bovine preovulatory follicles: gonadotropin surge and prostanoid-dependent up-regulation of genes potentially linked to the ovulatory process. Reproduction, 137(2):297-307.

Lobel BL, Levy E. 1968. Enzymic correlates of development, secretory function and regression of follicles and corpora lutea in the bovine ovary. Acta Endocrinol (Copenh), Suppl, 132:5-63.

Mamluk R, Levy N, Rueda B, Davis JS, Meidan R. 1999. Characterization and regulation of type a endothelin receptor gene expression in bovine luteal cell types. Endocrinology, 140(5):2110-2116.

Mishra S, Palai T. 2014. Steroidogenesis in luteal cell: a critical pathway for progesterone production. $J$ Invest Biochem, 3(4):170-172.

Miyamoto A, Shirasuna K, Shimizu T, Bollwein H, Schams D. 2010. Regulation of corpus luteum development and maintenance: specific roles of angiogenesis and action of prostaglandin F2alpha. Soc Reprod Fertil Suppl, 67:289-304.

Murdoch WJ, Steadman LE. 1991. Investigations concerning the relationship of ovarian eosinophilia to ovulation and luteal function in the sheep. Am J Reprod Immunol, 25(2):81-87.

Murdoch WJ, McCormick RJ. 1993. Mechanisms and Physiological implications of leucocyte chemoattraction into periovulatory ovine follicles. Reproduction, 97(2):375-380.

Murdoch WJ, Gottsch ML. 2003. Proteolytic mechanisms in the ovulatory folliculo-luteal transformation. Connect Tissue Res, 44(1):50-57.

Niswender GD., Juengel JL, McGuire WJ, Belfiore CF, Wiltbank MC. 1994. Luteal function: the estrous cycle and early pregnancy. Biol Reprod, 50(2):239-247.

Oakley OR, Kim HY, El-Amouri I, Lin PCP, Cho J, Bani-Ahmad M, Ko C. 2010. periovulatory leukocyte infiltration in the rat ovary. Endocrinology, 151(9):4551-4559.

Okuda K, Sakumoto R, Uenoyama Y, Berisha B, Miyamoto A, Schams D. 1999. Tumor necrosis factor alpha receptors in microvascular endothelial cells from bovine corpus luteum. Biolf Reprod, 61(4):1017-1022.

Okuda K, Sakumoto R. 2003. Multiple roles of TNF super family members in corpus luteum function. Reprod Biol Endocrinol, 1:95.

Okuda K, Korzekwa A, Shibaya M, Murakami S, Nishimura R, Tsubouchi M, Woclawek-Potocka I, Skarzynski DJ. 2004. Progesterone is a suppressor of apoptosis in bovine luteal cells. Biol of Reprod, 71(6):2065-2071.

Park, JY, Su YQ, Ariga M, Law E, Jin CSL, Conti M. 2004. EGF-like growth factors as mediators of LH action in the ovulatory follicle. Science, 303(5658):682684.

Pate JL. 2003. Lives in the Balance: responsiveness of the corpus luteum to uterine and embryonic signals. Reprod Suppl, 61:207-217.

Pate JL, Toyokawa K, Walusimbi S, Brzezicka E. 2010. The interface of the immune and reproductive systems in the ovary: lessons learned from the corpus luteum of domestic animal models. Am J Reprod Immunol, 64(4):275-286. 
Penny LA, Armstrong D, Bramley TA, Webb R, Collins RA, Watson ED. 1999. Immune cells and cytokine production in the bovine corpus luteum throughout the oestrous cycle and after induced luteolysis. J Reprod Fertil, 115(1):87-96.

Petroff MG, Petroff BK, Pate JL. 2001. Mechanisms of cytokine-induced death of cultured bovine luteal cells. Reproduction, 121(5):753-760.

Petrovská M, Dimitrov DG, Michael SD. 1996. Quantitative changes in macrophage distribution in normal mouse ovary over the course of the estrous cycle examined with an image analysis system. Am J Reprod Immunol, 36(3):175-783.

Poole DH, Pate JL. 2012. Luteal microenvironment directs resident $\mathrm{T}$ lymphocyte function in cows. Biol Reprod, 86(2):1-10.

Poulsen LC, Englund ALM, Wissing MLM, Yding Andersen C, Borup R, Grøndahl ML. 2019. Human granulosa cells function as innate immune cells executing an inflammatory reaction during ovulation: a microarray analysis. Mol Cell Endocrinol, 486:34-46.

Ramadan AA, Selim SA, Hassan HM, Wahba MA 2001. Immune regulation of ovarian function in buffaloes (Bubalus Bubalus). Theriogenology, 55(2):661-669.

Reibiger I, Spanel-Borowski K. 2000. 'Difference in Localization of Eosinophils and Mast Cells in the Bovine Ovary’. J Reprod Fertil, 118(2):243-249.

Reynolds LP, Redmer DA. 1999. Growth and development of the corpus luteum. J Reprod Fertil Suppl, 54:181-191.

Reynolds LP, Grazul-Bilska AT, Redmer DA. 2000. Angiogenesis in the corpus luteum. Endocrine, 12(1):1-9. Reynolds LP, Redmer DA. 1999. Growth and Development of the Corpus Luteum. J Reprod Fertil Suppl, 54:181-191.

Richani D, Gilchrist RB. 2018. The epidermal growth factor network: role in oocyte growth, maturation and developmental competence. Hum Reprod Update, 24(1):1-14.

Richards, JAS, Liu Z, Shimada M. 2008. Immunelike mechanisms in ovulation. Trends Endocrinol Metab, 19(6):191-196.

Richards JS, Russell DL, Ochsner S, Espey LL. 2002. Ovulation: new dimensions and new regulators of the inflammatory-like response. Annu Rev Physiol, 64:69-92.

Ritter LJ, Sugimura S, Gilchrist RB. 2015. Oocyte induction of EGF responsiveness in somatic cells is associated with the acquisition of porcine oocyte developmental competence. Endocrinology, 156(6):2299-2312.

Robinson RS, Woad KJ, Hammond AJ, Laird M, Hunter MG, Mann GE. 2009. Angiogenesis and vascular function in the ovary. Reproduction, 138(6):869-881.

Rohm F, Spanel-Borowski K, Eichler W, Aust G. 2002. Correlation between expression of selectins and migration of eosinophils into the bovine ovary during the periovulatory period. Cell and Tissue Res, 309(2):313-322.

Rosiansky-Sultan M, Klipper E, Spanel-Borowski K, Meidan R. 2006. Inverse relationship between nitric oxide synthases and endothelin-1 synthesis in bovine corpus luteum: interactions at the level of luteal endothelial cell. Endocrinology, 147(11):5228-5235.

Rueda BR, Hendry IR, Hendry III WJ, Stormshak F, Slayden OD, Davis JS. 2000. Decreased Progesterone Levels and progesterone receptor antagonists promote apoptotic cell death in bovine luteal cells. Biol Reprod, 62(2):269-276.

Sakumoto R, Berisha B, Kawate N, Schams D, Okuda K. 2000. Tumor necrosis factor-alpha and its receptor in bovine corpus luteum throughout the estrous cycle. Biol Reprod, 62(1):192-199.

Schams D, Kosmann M, Berisha B, Amselgruber WM, Miyamoto A. 2001. Stimulatory and synergistic effects of luteinising hormone and insulin like growth factor 1 on the secretion of vascular endothelial growth factor and progesterone of cultured bovine granulosa cells. Exp Clin Endocrinol Diabetes, 109(3):155-162.

Schruefer R, Lutze N, Schymeinsky J, Walzog B. 2005. Human Neutrophils Promote angiogenesis by a paracrine feedforward mechanism involving endothelial interleukin-8. Am J Physiol Heart Circ Physiol, 288(3):H1186-1192.

Sheldon IM, Price SB, Cronin J, Gilbert RO, Gadsby JE. 2009. Mechanisms of Infertility associated with clinical and subclinical endometritis in high producing dairy cattle. Reprod Domest Anim, 3(Suppl 44):1-9.

Shimada M, Hernandez-Gonzalez I, GonzalezRobayna I, Richards JS. 2006. Paracrine and autocrine regulation of epidermal growth factor-like factors in cumulus oocyte complexes and granulosa cells: key roles for prostaglandin synthase 2 and progesterone receptor. Mol Endocrinol, 20(6):1352-1365.

Shirasuna K, Nitta A, Sineenard J, Shimizu T, Bollwein H, Miyamoto A. 2012a. Vascular and immune regulation of corpus luteum development, maintenance, and regression in the cow. Domest Anim Endocrinol, 43(2):198-211.

Shirasuna K, Jiemtaweeboon S, Raddatz S, Nitta A, Schuberth HJ, Bollwein H, Shimizu T, Miyamoto A. 2012b. Rapid Accumulation of polymorphonuclear neutrophils in the corpus luteum during prostaglandin $\mathrm{F}(2 \alpha)$-induced luteolysis in the cow. PloS One, 7(1):e29054.

Shirasuna K, Asaoka A, Acosta TJ, Wijayagunawardane MPB, Ohtani M, Hayashi M, Matsui M, Miyamoto A. 2004. Real-time relationships in intraluteal release among prostaglandin F2alpha, endothelin-1, and angiotensin II during spontaneous luteolysis in the Cow. Biol Reprod, 71(5):1706-1711.

Skarzynski DJ, Okuda K. 1999. Sensitivity of bovine corpora lutea to prostaglandin F2alpha Is dependent on progesterone, oxytocin, and prostaglandins. Biol Reprod, 60:1292-1298.

Smith, GW, Meidan R. 2014. Ever-Changing Cell interactions during the life span of the corpus luteum: relevance to luteal regression. Reprod Biol, 14(2):75-82. Spanel-Borowski K, Rahner P, Ricken AM. 1997. Immunolocalization of CD18-positive cells in the bovine Ovary. J Reprod Fertil, 111(2):197-205.

Spanel-Borowski K. 2011. Ovulation as danger signaling event of innate immunity. Mol Cell Endocrinol, 
333(1):1-7.

Standaert FE, Zamora CS, Chew BP. 1991. Quantitative and qualitative changes in blood leukocytes in the porcine ovary. Am J Reprod Immunol, 25(4):163168.

Takeda K. 2004. Toll-like receptors in innate immunity. Int Immunol, 17(1):1-14.

Thatcher WW, Santos JEP, Silvestre FT, Kim IH, Staples CR. 2010. Perspective on physiological/ endocrine and nutritional factors influencing fertility in postpartum dairy cows. Reprod Domest Anim, 45(3):2-14.

Townson DH, O'Connor CL, Pru JK. 2002. Expression of monocyte chemoattractant protein-1 and distribution of immune cell populations in the bovine corpus luteum throughout the estrous cycle. Biol Reprod, 66(2):361-366.

Townson DH, Liptak AR. 2003. Chemokines in the corpus luteum: implications of leukocyte chemotaxis. Reprod Biol Endocrinol, 94(1):1477-7827.

Tropea A, Miceli F, Minici F, Tiberi F, Orlando M, Gangale MF, Romani F, Catino S, Mancuso S, Navarra P, Lanzone A, Apa R. 2006. Regulation of vascular endothelial growth factor synthesis and release by human luteal cells in vitro. Clin Endocrinol Metab, 91(6):2303-2309.

Tsai SJ, Wiltbank MC. 1998. Prostaglandin F2 $\alpha$ regulates distinct physiological changes in early and mid-cycle bovine corpora lutea1. Biol Reprod, 58(2):346-352.

Turner EC, Hughes J, Wilson H, Clay M, Mylonas KJ, Kipari T, Duncan CW, Fraser HM. 2011. Conditional ablation of macrophages disrupts ovarian vasculature. Reproduction, 141(6):821-831.
Walsh SW, Mehta JP, McGettigan PA, Browne JA, Forde N, Alibrahim RM, Mulligan FJ, Loftus B, Crowe MA, Matthews D, Diskin M, Mihm M, Evans AC. 2012a. Effect of the metabolic environment at key stages of follicle development in cattle: focus on steroid biosynthesis. Physiol Genomics, 44(9):504-517.

Walsh SW, Fair T, Browne JA, Evans ACO, McGettigan PA. 2012b. Physiological status alters immunological regulation of bovine follicle differentiation in dairy cattle. $J$ Reprod Immunol, 96(12):34-44.

Watanabe H, Tatsumi K, Yokoi H, Higuchi T, Iwai M, Fukuoka M, Fujiwara H, Fujita K, Nakayama H, Mori T, Fujita J. 1997. Ovulation defect and its restoration by bone marrow transplantation in osteopetrotic mutant mice of MitfMi/MitfMi genotype1. Biol Reprod, 57(6):1394-1400.

Woad KJ, Hammond AJ, Hunter M, Mann GE, Hunter MG, Robinson RS. 2009. FGF2 Is crucial for the development of bovine luteal endothelial networks in vitro. Reproduction 138(3):581-588.

Yamashita H, Kamada D, Shirasuna K, Matsui M, Shimizu T, Kida K, Berisha B, Schams D, Miyamoto A. 2008. Effect of Local Neutralization of basic fibroblast growth factor or vascular endothelial growth factor by a specific antibody on the development of the corpus luteum in the cow. Mol Reprod Dev, 75(9):14491456.

Zalman Y, Klipper E, Farberov S, Mondal M, Wee G, Folger JK, Smith GW, Meidan R. 2012. Regulation of Angiogenesis-related prostaglandin f2alpha-induced genes in the bovine corpus luteum. Biol Reprod, 86(3):1-10. 